\title{
Assessment of Health Related Fitness among Inmates of Reform and Rehabilitation Centers in Jordan
}

\author{
Mahmoud Mousa Al-Shudifat \\ Hashem Adnan Kilani
}

Health and Recreation Department, Faculty of Physical Education, The University of Jordan, Amman, Jordan

doi: 10.19044/esj.2016.v12n35p284 URL:http://dx.doi.org/10.19044/esj.2016.v12n35p284

\begin{abstract}
The Directorate of General Security in Jordan has created sport fields in new prisons, taking into consideration its importance for inmates. This is due to the belief that prisoners should be encouraged to spend interesting times, discharge their repressed energies, and to improve their physical and mental states in addition to strengthening their social relations. Providing members and specialist officers to attend to the inmates may decrease the problems inside prisons. This, however, can be achieved by engaging them with different kinds of physical activities. The purpose of this study is to evaluate the level of health-related fitness of the inmates in the reform and rehabilitation centers in Jordan and to differentiate between them according to the time span spent in the prison.

The study sample consisted of 208 inmates who volunteered to participate in the tests out of 2400 inmates in the center. They were classified into different age categories and their condemnation period. The tests contained the health related physical fitness elements: muscle power, respiratory endurance, muscle strength, flexibility, and body composition in terms of body mass index.

Results showed that there were statistical differences between the categories in this study in some tests. In conclusion, inmates should undergo physical programs to prevent them from contacting non-communicable diseases due to hypokinetic and sedentary life.
\end{abstract}

Keywords: Fitness, Health, Reform and Rehabilitation Centers

\section{Introduction}

Health fitness is considered as one of the most important bases of the human life whether the individual is athletic or non-athletic. This is because it is considered as an important part of the general fitness of human being. 
Also, it is one of the comprehensive elements for fitness alongside the mental, psychological, and social fitness that qualifies human being to live in a balanced status in the society (Abbas, Eiman, Najem Al-deen, et al., 2013).

In his world, inmates live in a place isolated from the civil society. This serves as a kind of a punishment to them, and it lasts for a certain period of time including life detention. The prevailing view about the prisons implies that they are bad places. However, the fact implies that they can sometimes be much better when viewed from the outside. Due to its welfare and luxury, staying in a prison can be considered just like a pleasant stroll.

Here are some of the prisons which are different from the other prisons in the world. This is because they are characterized by the provision of an excellent rehabilitation life as well as taking care of the inmates with regards to food, water, and education in addition to physical activity and proper health care.

1. The Norwegian Bastøy Prison, which includes about 100 inmates who live in huts overlooking the sea. However, these inmates spend their time in horse riding, sunbathing, fishing, camping, and playing tennis. In addition, they are supposed to work in the prison's farm and eat from what is grown and produced in this farm (http://www.takepart.com/photos/worlds-most-luxurious-prisons/bastoyprison-norway, 2015) (Appendix 1)

2. Leoben Justice Center in Austria. The criminals are sure that some prisons are better than the houses which people live. Each prison cell includes a kitchen, bathroom, and a cupboard (https://en.wikipedia.org/wiki/Justice_Center_Leoben).

3. Pondok Bambu Prison in Indonesia. If you have so much money, you won't like to spend imprisonment period in an ordinary prison cell, instead you will spend it in a hotel-like prison with firm restraint. This luxurious prison looks better than many of the four-star hotels and doesn't look like a place for spending the time of punishment. This type of prisons demonstrates the amount of corruption that takes place in the prison sector in this area. Each prison cell was designed in a certain way, where it contains suitable furniture, karaoke devices, a refrigerator, a bathroom, a personal space, as well as an air conditioning system (http://www.thejakartapost.com/news/2009/03/24/artalyta-transferredpondok-bambu-prison.html).

4. The Federal Correctional Institution, Sheridan, is one of the luxurious prisons for male inmates in Oregon. It gives the inmates the opportunity to start a new profession instead of continuing in the path of crimes. It is clear that changing the professional path requires innovation and the ability to adapt. However, it is not difficult in such a case where the inmates learn simple jobs, such as a physical fitness trainer or gardens coordinator 
(Mortenson, 1989;

Retrieved 2009-08-22

https://www.bop.gov/resources/pdfs/ipaabout.pdf).

5. Montgomery Federal Prison. It is just like Sheridan Institution. This prison, which is situated in Alabama, gives the inmates the opportunity to change their life from being criminals into new characters who work in new jobs, such as a cooker, a painter, attorney assistant, as well as many other professions. This provides a golden opportunity for those who wish to leave the life of crime and to live honorably.

6. The Federal Correctional Institution, Englewood. It is one of the luxurious prisons for male inmates in Colorado. It is located on the summit of Mount Rocky. Inmates in this prison can spend their time in playing billiards and table tennis. It usually includes a small number of inmates, and it is still a very modern prison since it has been built for about 20 years. In addition, it gives the inmates the opportunity to enjoy their time and to take advantage of the large area.

7. Duluth Federal Prison. If the inmate is interested in music, then Duluth Federal Prison in Minnesota is the best place to spend the period of imprisonment. In this prison, there are a number of musical instruments, such as the piano, the guitar, and drums.

8. Bastrop Federal Correctional Institution. This prison which is situated in Texas, USA, is characterized by being too close to Osten Airport with a distance of not more than $48 \mathrm{~km}$. This shows that the inmate can receive as many visitors as he wishes. Nevertheless, this does not mean that the possibility of escaping outside the country is easy, since the prison is under firm guardianship.

9. Oxford Federal Correctional Institution. Although Oxford Federal Correctional Institution, in Wisconsin, USA, does not have the real luxury of the English name that it holds, it provides its inmates with the potential to participate in the aerobic, art, and nutritional courses.

10. Schuylkill Federal Correctional Institution. We may consider Schuylkill Federal Correctional Institution, in Pennsylvania, USA, as a cultural and sporting collection, where the prison contains sporting teams, playing yards, and center for handcrafts. Furthermore, it encourages the inmates to do their best in order to enjoy their incarceration period in this clublike prison.

11. Lompoc Prison, which is located in California in the United States, has marvelous gardens of eucalyptus. This makes the experience of being imprisoned there like a pleasant stroll. Thus, the surrounding walls of the prison prevent you from enjoying more natural sights. There used to be tennis pitches, but were removed so that the inmates can only enjoy playing baseball and volleyball. 
12. Butner Federal Correctional Institution. This prison, which is located in North Carolina, USA, gained fame after Jeff Skilling was imprisoned there due to crimes related to the Enron Scandal. The prison is characterized by a high extent of luxury, in that one of the judges suggested that the prosecutor should go and have a vacation in that prison.

13. The County Prison in Los Angeles has units for those with special needs. Although it is one of the firm prisons in which the inmates may be exposed to shooting by snipers if they tried to walk inside the prison at night. This treatment changes at about 180 degrees in the units of those with special needs which is characterized by the simple status of living without any difficulties as well as the existence of a public phone (California State Prison, Los Angeles County (LAC), 2009).

In Jordan, the prisons are called reform and rehabilitation centers. It is a place where a certain part of the society spend their freedom detention period as punishment for a crime committed by someone. Also, prisons can affect the physical and mental health if we do not take into account some important issues such as exercises, food, exposure to sunlight, and deep sleep (Kilani et al., 2013).

Jordan utilized their partnership with the European Union and the United States by building modern prisons that have courtyards containing playgrounds of football, basketball, handball, and rooms for drawing. This is in addition to developing workshops for teaching the activities of blacksmithing, carpentry, as well as the restructuring and painting of cars.

The average number of inmates in these centers is 8000 inmates, representing a percentage of $13 / 10000$ of the total population (the Department of Reform and Rehabilitation Centers, 2015). As a result, this imposes extra money and effort in case one of those inmates was exposed to the different diseases that prevail in the environment in which they live. Due to the importance of the physical activities in providing the inmates with the ability to improve their health and psychological status, the Public Security Directorate developed sports arenas in the new prisons. They took into account the importance of exercise for the inmates and encouraged them to have a good time in those playgrounds as well as benefiting from them in projecting their suppressed energies and improving their physical and psychological state. Consequently, this is in addition to strengthening the social relationships and reducing the problems inside these prisons while providing professional members and officers to help them in practicing the various types of sports. 


\section{The Statement of the Problem}

Human being is exposed to increasing risk factors by sedentary lifestyle diseases and other types of this age diseases in case of not practicing the activities that help him build a body that is capable of performing his daily and life duties in an optimal manner. Due to the presence of a part of these persons in circumstances that are beyond their control and their status as inmates in the reform and rehabilitation centers, they may suffer from a bad psychological state and deteriorating physical health. The prisons administrators could avoid these conditions by providing the potentials and supplies that encourage them to go out in order to vent the frustration and suppression in which they live. This in turn has a positive impact on their health, and consequently provides a lot of effort and money saving for the state.

Many countries afford too many expenses due to the problems and difficulties suffered by the inmates in the reform and rehabilitation centers regarding the health issues that result from the nature of imprisonment that they were exposed to due to legal issues. Accordingly, these inmates will suffer from health problems which could lead to difficulties related to the lack of physical activities. As a result, the state will be committed to treat those inmates inside these centers or in/outside hospitals. This involves addressing the issue of security and physical disadvantages by encouraging them to practice physical activities and by providing them playgrounds and specialized trainers. Thus, it is necessary to detect the health and physical level of the inmates by providing them with the battery of physical fitness that is related to health. This is in a bid to contribute in treating such difficulties relating to lack of movement.

\section{The Significance of the Study}

It is well known that physical fitness is important for all the individuals in the society as well as the inmates of these centers due to its physical, psychological, and social benefits that would contribute to qualifying the inmate so that he would return back to his society without complex psychological effects that suppress his freedom in these reform centers. There is a significant relationship between the good physical fitness and good health since the individuals who live inactive life are more vulnerable to disease over time. These diseases include obesity, high body fat percentage, and the problems of heart and blood vessels, as well as their complications.

Furthermore, individuals who do not practice regular physical activities may suffer from diseases of the joints and muscles. Thus, maintaining the good physical fitness by sports and nutrition are considered 
optimal protective factors regarding keeping healthy conditions in the different life stages (Kilani, 2015).

Since the period spent by the inmate may affect the physical and health level, the questions of the study were raised based on the effect of time duration spent by the inmate in the reform and rehabilitation center on his physical and health status.

Some elements of physical fitness that were selected are Cooper test, flexibility, and strength of the arms. Also, the test of a modified sit up was conducted, while body mass index was used instead of the body composition test.

\section{The Theoretical Framework of the Study The Nature of Fitness}

It is simply the heart, lungs, blood vessels, and muscle's ability to work in the optimum case which is represented by the economy of effort and the increase in efficiency. Being physically fit is considered as a state of good health integration. This is such that we can use most of our inherent capabilities to achieve our work such as cultivation of the land, house cleaning or trimming and cleaning of the weeds from the garden, and other daily actions that the human can be exposed to as a part of the daily routine. Therefore, the meaning of life would be more interesting when we enjoy and spend our time with vitality and activity.

Therefore, there are five elements of physical fitness:

1. The Cardiorespiratory Endurance: It is the ability of the heart and lungs to provide the oxidized blood to the working muscles. By increasing the efficiency of the heart and lungs, this element develops, and it can be measured by several tests including the use of gas analysis device, treadmill, and field (Cooper) test.

2. The Muscular Strength: The maximum effort made against resistance for one repetition which can be measured by using the hand grip (Dynamometer) as well as other devices.

3. The Muscular Endurance: It is defined as the ability to perform repeated contractions such as the number of repetition of the muscles exercise at once. This is like a muscular strength where the exercise will be particular for the working muscles. Both are very important to prevent lower back pain. As reported in this study, this element can be measured by the sit-up and the push-up exercises.

4. Flexibility: The ability of the joint to move in a full range of motion measured by angle, but the lack of this element in the appropriate manner provides the likelihood of sports injuries.

5. Body Composition: It consists of lipid weight (obesity) and body weight (muscles, bone and tissues). The weight ratio of lean to fat changes with 
age, so that at least the ratio of lean decreases, while the ratio of fat increases. However, the use of aerobic exercise (exercises that stimulates and strengthens the heart and the lungs, whereby the muscular contractions depends on the availability of oxygen and burning fat, such as the sport of long walking, running, and fitness) slows down this natural change due to the burning of fat as an energy source, and it helps in building the muscles and maintaining its tones (Kilani, 2006).

The body mass index (BMI) was used as a scale that reflects body composition for the difficulty of measuring the fat ratio of the study sample.

\section{The Law of the Jordanian Reform and Rehabilitation Center}

The law of the Jordanian reform and rehabilitation center number (9) for year 2004 which was published in the formal newspaper numbers 4656 in 29/4/2004 was issued in order to organize the work of these centers. This law takes into consideration the rights of the inmates in all the domains, as well as their duties. This law was consistent with the rules that were recommended by the codes of the United Nations during the first conference to prevent crime and the treatment of criminals which was held in Geneva in 1955. It was approved by social and economical council with its two decisions (633) in 31 July 1957 and (2076/d-62) in 13 May 1977. These decisions recognized the rights of the inmates to education and luxury as cited in section 78 (cultural and recreational activities should be organized in prisons in order to maintain the mental and physical luxury of the inmates).

They also gave a recommendation about discrimination of treatment with inmates who are imprisoned based on financial issues (debts). Here, less firm regulations are applied to them in comparison with criminals.

The inmates in Jordan receive the healthcare by the Ministry of Health either in the center or in the health centers and hospitals that belong to them. This is in coordination with the public security directorate/the department of reform. The inmates are also taken out to the sunny areas by the officers and the members who are responsible for the administration of the center according to a certain program which guarantees that the inmates won't escape or do any violations of the law against their colleagues. Also, it allows them to practice sports in the arenas and stadiums which are located within the walls of the center.

The inmates are also provided with three meals a day, which are good enough in terms of quality and quantity. Also, their meal is similar to those given to the prison guards as members and officers of the Public Security. In addition, there is a supermarket in all the centers, where the merchandise are sold to the inmates' guests, and this gives the inmates the option of not eating the meals offered to them by the management of the Centre. 
The researchers in this study illustrated that the studies are very few in this area due to the targeted group in this study.

\section{The Study Objectives}

The study aims at:

1. Identifying the level of health-related physical fitness among the inmates of reform and rehabilitation centers.

2. Identifying the differences between inmates regarding the level of healthrelated physical fitness which are attributed to the period that the inmates spend in the reform and rehabilitation centers.

3. Identifying the degree at which the inmates have health-related physical fitness in comparison with the international standards.

Therefore, the questions and hypotheses of the study are:

1. There are no differences in the level of health-related physical fitness attributed to the period that the inmates spend in the reform and rehabilitation centers.

2. What is the level of health-related physical fitness among a sample of inmates in comparison with the international standards?

\section{The Terminology of the Study}

The Reform and Rehabilitation Center has been in the second section of the Law of Correction and Rehabilitation Centers No. (9) of 2004, which was published in the Official Journal No. (4656) in 29-4-2004.

The reforms and rehabilitation centers are punitive institutions where the person spends the period of imprisonment as a result of violating the laws, taking into account the commitment to the humanitarian principles in treatment.

The same section of the law defines the inmate as the person, male or female, who is imprisoned in the center to implement any decision issued by a judicial authority or any competent authority.

\section{The Study Limitations}

The Spatial Domain: Reform and Rehabilitation Center, Sewaqa, The Hashemite Kingdom of Jordan.

The Human Domain: The inmates of Swaqa's reform and rehabilitation Center.

The Temporal Domain: April 2014 to August 2014.

\section{Methods}

The researchers used the descriptive approach due to its appropriateness to the nature of the study.

Population: The inmates of the reform and rehabilitation centers in Jordan have a total number of 8000 inmates. 
The Study Sample: The Rehabilitation Center of Sewaqa was selected for testing. The study sample consisted of 208 inmates who volunteered to participate in the tests out of 2400 inmates in the center. Tables $1 \& 2$ below describe the sample:

Table 1. Means and standard deviations (SD) of age, height, and weight

\begin{tabular}{ccc} 
Variables & Mean & SD \\
\hline Age & 29.68 & 7.60 \\
Height & 171.63 & 6.25 \\
Weight & 72.28 & 10.96 \\
\hline
\end{tabular}

Table 2. Description of the imprisonment period and the time served for the inmates in the reform and rehabilitation Centers

\begin{tabular}{ccccc} 
Variables & $\begin{array}{c}\text { Minimum } \\
\text { period }\end{array}$ & $\begin{array}{c}\text { Maximum } \\
\text { Period }\end{array}$ & Mean & SD \\
\hline Imprisonment period & 0.20 & 20.0 & 6.13 & 4.16 \\
$\begin{array}{c}\text { (years) } \\
\text { Served time (years) }\end{array}$ & 0.10 & 17.0 & 3.14 & 2.64 \\
\hline
\end{tabular}

The data in table 2 show that the minimum condemnation period was 0.20 years; i.e. two months and 12 days. On the other hand, the maximum duration of condemnation was 20 years. It was also indicated that the least period that was spent in correctional and rehabilitation centers was 0.10; i.e. one month and six days. Also, the maximum period that was spent there was 17.0 years.

The value of the Mean for the Condemnation period was 6.13 years, while the value of the Mean for the spent Condemnation period was 3.14 years.

\section{Results}

This study aims at identifying the level of health-related physical fitness among a sample of inmates in the reform and rehabilitation centers. Table 3 illustrates that the value of the mean for the exercise of measuring the muscular strength for the sample is 21.87. This is with a standard deviation of 11.34, while the arithmetic mean of the muscular endurance of the sample was 26.24 with a standard deviation of 9.47. As for the cardiorespiratory endurance, the arithmetic mean of the sample was 20.39 with a standard deviation of 3.38, while the arithmetic mean of the sample regarding flexibility was 4.35 with a standard deviation of 9.88. In addition, the arithmetic mean of the BMI of the sample was 24.5 with a standard deviation of 3.54 . 
Table 3. Means and Standard Deviations of the elements of health-related fitness for the inmates in the reform and rehabilitation centers

\begin{tabular}{ccc} 
Variable & $\begin{array}{c}\text { Arithmetic } \\
\text { Mean }\end{array}$ & Standard Deviation \\
\hline Muscular Strength & 21.87 & 11.34 \\
Muscular Endurance & 26.24 & 9.47 \\
Cardiorespiratory Endurance & 20.39 & 3.38 \\
Flexibility & 4.35 & 9.88 \\
Body Mass Index & 24.5 & 3.54 \\
\hline
\end{tabular}

The second objective of the study was to identify the differences between the inmates' level of health-related physical fitness attributed to the served period that the inmate spends in the reform and rehabilitation centers. According to the illustration on Table 4, there are differences between the elements of the health-related physical fitness. In order to verify the importance of these differences, the researcher used the ANOVA test. Thus, the results of this analysis are shown in Table 5.

Table 4. Means and Standard Deviations of the elements of fitness distributed according to the variable of time served in the center

\begin{tabular}{|c|c|c|c|c|}
\hline Variables & Served time & Number & $\begin{array}{l}\text { Arithmetic } \\
\text { mean }\end{array}$ & $\begin{array}{l}\text { Standard } \\
\text { Deviation }\end{array}$ \\
\hline \multirow[t]{4}{*}{ Muscular Strength } & Less than 6 months & 10 & 15.20 & 8.20 \\
\hline & $\begin{array}{c}6 \text { months- less than } 2 \\
\text { years }\end{array}$ & 98 & 23.72 & 10.65 \\
\hline & $\begin{array}{c}2 \text { years- less than } 5 \\
\text { years }\end{array}$ & 72 & 20.64 & 11.95 \\
\hline & 5 years or more & 28 & 20.93 & 12.12 \\
\hline \multirow[t]{4}{*}{ Muscular Endurance } & Less than 6 months & 9 & 26.44 & 7.21 \\
\hline & $\begin{array}{c}6 \text { months- less than } 2 \\
\text { years }\end{array}$ & 96 & 28.11 & 8.03 \\
\hline & $\begin{array}{c}2 \text { years- less than } 5 \\
\text { years }\end{array}$ & 71 & 24.73 & 10.46 \\
\hline & 5 years or more & 27 & 23.44 & 11.07 \\
\hline \multirow{4}{*}{$\begin{array}{l}\text { Cardiorespiratory } \\
\text { Endurance }\end{array}$} & Less than 6 months & 0 & 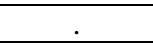 & - \\
\hline & $\begin{array}{c}6 \text { months- less than } 2 \\
\text { years }\end{array}$ & 40 & 20.49 & 3.78 \\
\hline & $\begin{array}{c}2 \text { years- less than } 5 \\
\text { years }\end{array}$ & 18 & 19.99 & 2.18 \\
\hline & 5 years or more & 8 & 20.81 & 3.75 \\
\hline \multirow[t]{4}{*}{ Flexibility } & Less than 6 months & 10 & 0.05 & 11.36 \\
\hline & $\begin{array}{c}6 \text { months- less than } 2 \\
\text { years }\end{array}$ & 94 & 4.35 & 9.93 \\
\hline & $\begin{array}{c}2 \text { years- less than } 5 \\
\text { years }\end{array}$ & 68 & 4.91 & 9.58 \\
\hline & 5 years or more & 25 & 4.56 & 10.08 \\
\hline \multirow[t]{4}{*}{ BMI } & Less than 6 months & 16 & 22.99 & 2.83 \\
\hline & $\begin{array}{c}6 \text { months- less than } 2 \\
\text { years }\end{array}$ & 53 & 24.06 & 3.10 \\
\hline & $\begin{array}{c}2 \text { years- less than } 5 \\
\text { years }\end{array}$ & 94 & 24.55 & 3.62 \\
\hline & 5 years or more & 45 & 25.44 & 3.89 \\
\hline
\end{tabular}


Table 5. ANOVA of the elements of health-related fitness depending on the variable of the time served in the center

\begin{tabular}{|c|c|c|c|c|c|c|}
\hline Variables & $\begin{array}{l}\text { Source of } \\
\text { variation }\end{array}$ & $\begin{array}{l}\text { Sum of } \\
\text { squares }\end{array}$ & $\begin{array}{l}\text { Degrees } \\
\text { of } \\
\text { freedom }\end{array}$ & $\begin{array}{c}\text { Mean } \\
\text { of } \\
\text { squares }\end{array}$ & $\begin{array}{c}\mathrm{F} \\
\text { value }\end{array}$ & $\begin{array}{c}\text { Significance } \\
\text { level }\end{array}$ \\
\hline \multirow[t]{3}{*}{$\begin{array}{l}\text { Muscular } \\
\text { Strength }\end{array}$} & $\begin{array}{c}\text { Between } \\
\text { groups }\end{array}$ & 915.87 & 3 & 305.29 & \multirow{3}{*}{2.42} & \multirow{3}{*}{0.067} \\
\hline & $\begin{array}{l}\text { Inside the } \\
\text { group }\end{array}$ & 25705.63 & 204 & 126.01 & & \\
\hline & Total & 26621.50 & 207 & & & \\
\hline \multirow[t]{3}{*}{$\begin{array}{l}\text { Muscular } \\
\text { Endurance }\end{array}$} & $\begin{array}{c}\text { Between } \\
\text { groups }\end{array}$ & 710.11 & 3 & 236.70 & \multirow{3}{*}{2.71} & \multirow{3}{*}{0.046} \\
\hline & $\begin{array}{l}\text { Inside the } \\
\text { group }\end{array}$ & 17394.54 & 199 & 87.41 & & \\
\hline & Total & 18104.65 & 202 & & & \\
\hline \multirow[t]{3}{*}{$\begin{array}{l}\text { Cardiorespiratory } \\
\text { Endurance }\end{array}$} & $\begin{array}{c}\text { Between } \\
\text { groups }\end{array}$ & 4.67 & 3 & 1.56 & \multirow{3}{*}{0.13} & \multirow{3}{*}{0.941} \\
\hline & $\begin{array}{l}\text { Inside the } \\
\text { group }\end{array}$ & 737.13 & 62 & 11.89 & & \\
\hline & Total & 741.80 & 65 & & & \\
\hline \multirow[t]{3}{*}{ Flexibility } & $\begin{array}{c}\text { Between } \\
\text { groups }\end{array}$ & 216.16 & 3 & 72.05 & \multirow{3}{*}{0.74} & \multirow{3}{*}{0.532} \\
\hline & $\begin{array}{l}\text { Inside the } \\
\text { group }\end{array}$ & 18909.27 & 193 & 97.98 & & \\
\hline & Total & 9125.43 & 196 & & & \\
\hline \multirow[t]{3}{*}{ BMI } & $\begin{array}{c}\text { Between } \\
\text { groups }\end{array}$ & 87.08 & 3 & 29.03 & \multirow{3}{*}{2.36} & \multirow{3}{*}{0.072} \\
\hline & $\begin{array}{l}\text { Inside the } \\
\text { group }\end{array}$ & 2505.68 & 204 & 12.28 & & \\
\hline & Total & 2592.76 & 207 & & & \\
\hline
\end{tabular}

The table shows that the calculated value of $\mathrm{F}$ for the variable of muscular strength measured by the exercise of bending and extending the arms was 2.42 with a level of significance of 0.067 . The value of the variable muscular tolerance measured by the exercise of sitting from lying posture, the stomach exercise, was 2.71 with a level of significance of .046. The value for respiratory periodic tolerance measured through the Cooper test was 0.13 with a level of significance of .941 . The Flexibility measured by the graded box was 0.74 with a level of significance of 0.532 , while the value for the variable of Body Mass Index was 2.36 with a level of significance of 0.072 . All the values of the level of significance have no statistical significance because they are larger than 0.05 except for the value of the significance level for the variable of muscular tolerance measured by the exercise of sitting from the lying position (stomach exercise) which was less than 0.05 . This, therefore, indicate that there are a statistically significant differences in this test between the periods that were spent in the center. 
In order to identify the sources of these differences and variations, Scheffé's test for post comparisons was used. Thus, Table 6 shows the results of this test:

Table 6. Scheffé's test for post comparisons in order to identify the sources of these differences in the variable of stomach exercise

\begin{tabular}{cccccc}
\hline Variables & Mean & Served time & $\begin{array}{c}6 \text { months- less } \\
\text { than 2 years }\end{array}$ & $\begin{array}{c}2 \text { years- less } \\
\text { than 5 years }\end{array}$ & $\begin{array}{c}5 \text { years or } \\
\text { more }\end{array}$ \\
\hline $\begin{array}{c}\text { Muscular } \\
\text { endurance }\end{array}$ & 26.44 & $\begin{array}{c}\text { Less than } 6 \\
\text { months }\end{array}$ & \\
\cline { 2 - 5 } & $\begin{array}{c}\text { 6 months - less } \\
\text { than 2 years }\end{array}$ & \\
\cline { 2 - 5 } & $\begin{array}{c}2 \text { years - less } \\
\text { than 5 years }\end{array}$ \\
\cline { 2 - 5 } 24.73 & $\begin{array}{c}5 \text { years or } \\
\text { more }\end{array}$ \\
\hline
\end{tabular}

The listed results indicate that there are differences between the individuals whose imprisonment period is six months - less than 2 years, and individuals whose imprisonment period is five years or more. This was such that the significance of these differences was in favor of those who spent a period of 6 months - less than two years, in that their arithmetic mean value was the highest.

The third objective of the study is to identify the extent to which inmates have the health-related physical fitness in comparison with the globally approved standards. The average age of the sample is less than 30 years, and it has an arithmetic average of 21.87, and a standard deviation of 11.34. This is seen with regards to the muscular strength which is considered as weak according to the international standards of fitness which falls between 20 - 35 (Table 7). The average muscular tolerance was 26.24 with a standard deviation of 9.47, which is located in the medium category according to the international standards (Table 8). However, the average of the respiratory periodic tolerance of the sample is 20.39 with a standard deviation of 3.38, which is considered as weak according to the International Standards of Fitness (Table 9). The average of the flexibility of the sample is 4.35 with a standard deviation of 9.88, which is considered to be less than average according to the international standards of fitness (Table 10). As for the body mass index, the average of the sample is 21.13 with a standard deviation of 3.42, which is considered as suitable according to the International Standards of Fitness (Table 11).

\section{Discussion}

In order to answer the first hypothesis, which states that there are no differences in the level of the elements of health-related fitness attributed to the period served in the reform and rehabilitation center, Table 4 shows that 
there are no statistical significant differences related to the time the inmate spends in the reform and rehabilitation centers. Also, the muscular endurance test shows that there are statistically significant differences at the level 0.05 in favor of the period of 6 months up to two years (Table 6). Therefore, the hypothesis is rejected as it was based on the idea that the center is one and that the activities and food are for all. However, the served period was one of the factors that contributed to the difference in the level of health-related physical fitness although the study of Al-Kharoof (2003) demonstrates positive trends towards the physical activity regardless of the served period.

As for the second question, which states: Is there any effect for the period that the inmate spends in the reform and rehabilitation centers? The researcher through Table 3 suggest that the period that the inmate spends in the reform and rehabilitation centers has negative effects on their fitness due to reasons related to their psychological status. Thus, thinking about their humanitarian and familial status makes them feel bored, depressed, and not willing to do any physical activity in order to improve their physical fitness (Zayed \& Kilani, 2014).

The results of the conducted tests (Table 3 and 4) were not consistent with the international standards of physical fitness towards health in comparison with Tables 7 to 11 . The lack of effective participation in the tests and leaving the tests by too many of those who have volunteered to participate in the study without asking for permission or without finding a reason to leave is evident by the difference in the numbers between the samples that were selected. This contravenes with the perspective of the researchers in the study of Al-Kharouf (2003) which concluded that the inmates are motivated to participate in the physical activities.

Based on the above, the researchers believe that despite the lack of similar researches on the targeted category of the research, comparing the study results with the global standards of fitness for health suggest that the inmates are not interested in the health-related physical fitness. Here, the sample gained an arithmetic average of 21.87 and a standard deviation of 11.34, regarding the muscular strength which is considered as weak according to the international standards of fitness (http://www.fitnessyard.com/articles-and-information/body-building).

\begin{tabular}{cccccc}
\hline \multicolumn{5}{c}{ Table 7. Cardiorespiratory endurance standard } & \\
\hline Age & $29-20$ & $39-30$ & $49-40$ & $59-50$ & $60+$ \\
\hline Excellent & More than 54 & More than 44 & More than 39 & More than 34 & More than 29 \\
\hline Good & $54-45$ & $44-35$ & $39-30$ & $34-25$ & $29-20$ \\
\hline Average & $44-35$ & $34-24$ & $29-20$ & $24-15$ & $19-10$ \\
\hline Weak & $34-20$ & $24-15$ & $19-12$ & $14-8$ & $9-5$ \\
\hline $\begin{array}{c}\text { Very } \\
\text { weak }\end{array}$ & Less than 20 & Less than 4 & Less than 3 & Less than 2 & Less than 1 \\
\hline
\end{tabular}


As for Cardiorespiratory endurance for the same category, it was within the average level with a mean of 20.39 and a standard deviation of 3.38. The traveled distance was measured in kilometers in order to compare the result in accordance with the taxonomic table of the international standards.

Table 8. Cooper test results for walking / running for 12 minutes

\begin{tabular}{|c|c|c|c|c|}
\hline Classification & $\begin{array}{c}\text { Less than } 30 \\
\text { years }\end{array}$ & 39- 30 years & 49-40 years & $\begin{array}{l}\text { More than } 50 \\
\text { years }\end{array}$ \\
\hline Very weak & $\begin{array}{c}\text { Less than } 1.60 \\
\text { km }\end{array}$ & $\begin{array}{c}\text { Less than } 1.52 \\
\text { km }\end{array}$ & $\begin{array}{c}\text { Less than } 1.36 \\
\text { km }\end{array}$ & $\begin{array}{c}\text { Less than } 1.28 \\
\text { km }\end{array}$ \\
\hline Weak & $1.99-1.60$ & $1.83-1.52$ & $1.67-1.36$ & $1.59-1.28$ \\
\hline Average & $2.39-2.01$ & $2.23-1.85$ & $2.07-1.68$ & $1.99-1.60$ \\
\hline Good & $2.80-2.41$ & $2.63-2.25$ & $2.47-2.09$ & $2.39-2.01$ \\
\hline Excellent & More than 2.80 & More than 2.63 & More than 2.47 & More than 2.39 \\
\hline
\end{tabular}

As for the muscular endurance (sit-up exercise), the average muscular endurance was 26.24 with a standard deviation of 9.47, which is located in the weak to medium category according to international standards regarding the inmates' age.

Table 9. Sit-up standards

\begin{tabular}{cccc}
\hline Age/ classification & Less than 35 & $35-44$ & More than 45 \\
\hline Excellent & 60 & 50 & 40 \\
\hline Good & 45 & 40 & 25 \\
\hline Average & 30 & 25 & 15 \\
\hline weak & 15 & 10 & 5
\end{tabular}

As for the test of flexibility, the average of flexibility of the sample is 4.35 with a standard deviation of 9.88 , which is considered to be less than average according to the international standards of fitness.

Table 10. Flexibility standards

\begin{tabular}{cc}
\hline Assessing flexibility & \\
\hline Excellent & More than $14 \mathrm{~cm}$ \\
\hline Good & $11-13$ \\
\hline Average & $7-10$ \\
\hline Less than average & $4-6$ \\
\hline weak & Less than 3
\end{tabular}

Table 11

Body Mass Index

(20) - (24.9) kg / m - suitable limits.

(25) - (29.9) $\mathrm{kg} / \mathrm{m}$ - an increase in weight.

If the body mass index exceeds $30 \mathrm{~kg} / \mathrm{m}$, it is an index of having obesity.

If the BMI exceeds $40 \mathrm{~kg} / \mathrm{m}$, it is the index of having too much obesity.

(wikipedia.org 2016) 
Since the sample falls in the first category regarding the mean of weight and the body mass index, the researchers attribute that to the limited meals that are given to the inmates in terms of calories and the lack of the food that cause obesity in their particular market inside the center. This makes the inmate weight within the suitable limits. On the other hand, the meals could be enough for some inmates, but not for others, taking into consideration that the sample is voluntary and was not chosen randomly. Therefore, it does not represent the normal distribution of the study population (Kilani \& Abu-Eishah, 2010).

\section{Conclusion}

Based on the results of the tests, the study concluded the following:

1. There is a general weakness in health-related physical fitness level attributed to the lack of attention to inmates by those who are in charge of the center regarding the improvement of the health and physical condition.

2. When the inmate spends longer period in the reform centers, his physical ability decreases regarding exerting more force during muscular effort.

\section{Recommendations}

1. The researchers recommend encouraging the inmates in the reform and rehabilitation centers to do sports activities through regulated and compulsory programs that are activated and traced by the senior management of the center.

2. Assign specialists to supervise the implementation of sports programs to suit all the ages in the centers and giving the inmates the freedom to choose the type of activity that they like, taking into account the regulations and laws.

3. Hiring counselors in order to encourage the inmates to practice sports activities and to get rid of frustration and depression, as well as providing lyrical and musical recordings that encourage them to improve their mental state and their desire to participate.

\section{References:}

1. Abbas, Eiman Najm Al-Deen et al. (2013). The impact of proposed exercises using elastic cords on some elements of physical fitness among students of Faculty of Physical Education at the University of Sulaymaniyah. Journal of Sports Science-fourth edition- the sixth Volume).

2. Alkharouf, K.M. (2003). Inmates' attitudes towards sports activities in rehabilitation centers in Jordan. Unpublished Master Thesis, University of Yarmouk. Irbed, Jordan 
3. California State Prison, Los Angeles County (LAC) (2009). "Mission Statement". California Department of Corrections and Rehabilitation. Archived from the original on August 6, 2009. Retrieved 2009-08-20.

4. http://www.bastoyfengsel.no/English

5. http://www.fitnessyard.com/articles-and-information/body-building

6. https://ar.wikipedia.org/wiki/

7. https://www.google.jo/search?q=prison+bastoy\&espv=2\&biw=1280 \&bih $=619 \&$ tbm $=$ isch\&tbo $=$ u\&source $=$ univ\&sa $=$ X\&ved $=0$ ahUKEwi sq52hwLXLAhXLWBoKHanrABUQsAQIJA\&dpr=1.5\#imgrc=S5m e7xbQL0jt7M\%3A

8. Jordanian Directorate of Public Security. (2015). Department of reform and rehabilitation centers.

9. Kilani, H. (2006). Physiology of physical effort. Amman: Haneen Publisher.

10. Kilani, H. (2015). Cardiovascular Diseases Risk, Energy Expenditure, and Health Fitness. Canad J Clin Nutr 2015; 3 (2): 1-4. DOI: http://dx.doi.org/10.14206/canad.j.clin.nutr.2015.02.013-

11. Kilani, H. \& Abu Eisheh, A. (2010). Optimum Anthropometric Criterion for Ideal Body Composition. SQU Med J, 10(1), 74-79.

12. Kilani, H., Al-Yarobi, S., Zayed, K., Alzakwani, I., Bererhi, H., Shukri, Alrasadi, K. (2013). Physical Fitness Attributes, Vitamin D, Depression, and BMD in Omani’s Children. Europ Sci J. 9(30), 156173.

13. Mortenson Eric (May 20, 1989). "Sheridan becomes a prison town". Register-Guard. pp. 1A and 4A. Retrieved 2009-08-22. https://www.bop.gov/resources/pdfs/ipaabout.pdf.

14. Zayed, K. \& Kilani, H. (2014). Physical Activity is Associated with Depression and Self-Esteem Levels among Omani Female Children. Canad J Clin Nutr , 2 (1): 5-18. DOI: http://dx.doi.org/10.14206/canad.j.clin.nutr.2014.01.03 


\section{Appendices}

Appendix 1. Shows an image of some of the facilities and rooms in Bastoy Prison

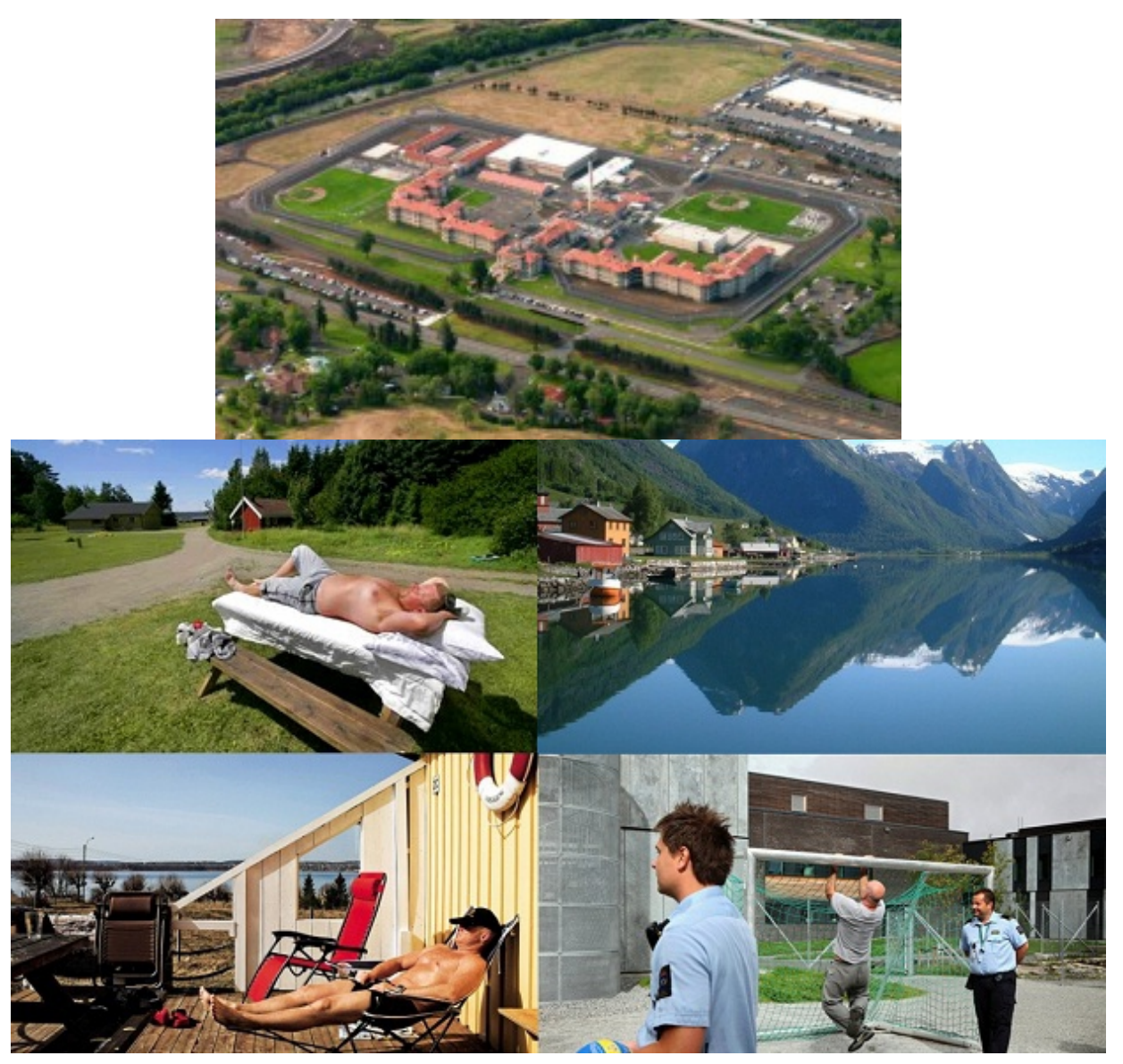

